of achievements of students with their delayed analysis by the brief form of achievements with operational analysis. The author has also suggested operational cross-sectional option of participants' survey, that can be performed by school psychologists, specialists of professional orientation, application committees, and even by a person him/herself. The adjustment of diagnostic tools of applied psychologists with the abovementioned methodologies can increase the quality of psychological support of professional self-determination of a personality during the life and as a result the quality of choice of professional education and job satisfaction.

Keywords: multidimensional theory of personality, professional orientation, occupational choice, personality of a participant, methodologies of multidimensional analysis of accomplishments of a participant: longitudinal and crosssectional variants.

Подано до редакиії 01.03.2016

UDC: 159.9

Tamara Plaksii,

PhD (Candidate of Historical Sciences), associate professor, Department of Psychology, Pedagogy and Philosophy,

Mykola Derkach,

fourth-year student, Faculty of Psychology,

Kremenchuk Mykhailo Ostrohradskyi National University, 20, Pershotravneva Str., Kremenchuk, Ukraine

\title{
FEATURES OF SENIOR CITIZENS' EMOTIONAL STATES UNDER THE CONDITIONS OF THE MODERN UKRAINIAN SOCIETY TRANSFORMATION
}

The article deals with the peculiarities of senior citizens' emotional states in the modern Ukrainian society. The main ways of interpreting the concepts of «emotions», «experience», "psychological states» have been considered in the study. It has been proved that hard life conditions may be manifested in the emotional sphere of elderly people and their psycho-physiological health. Besides, it has been found that their longevity depends on their life attitudes.

Keywords: emotions, emotional states, emotional suffering, emotional sphere, the old age, retirement age.

Problem statement. At the beginning of the $\mathrm{XX}$ century the age structure of population considerably changed, which was determined by the low level of birth, high death rate and the increase of the number of senior citizens. According to the UNO, the number of elderly people has increased fivefold over the last 50 years. Today every fifth citizen of Ukraine reached the age of 60 . In 1994, 14\% of citizens were 65 years old and older, and in 2025 , this percentage is assumed to increase to $21 \%$ [8]. The issue of ageing of Ukrainian population is thoroughly considered by the government, publicity, mass media and scientific communities.

Modern psychology pays special attention to the issue of person ageing, the life of people in the senior age, the influence of emotions of the ageing processes, etc. However, the insufficiency of the phenomenological material, complexity of its empirical studying, as well as the limitation of the methodological approaches are considered to be the obstacles for the creation of the theory of changes and development of a personality throughout life.

One of the main human features is taking care of elderly people as the guardians of the psychosocial experience and the source of wisdom. Unfortunately, by the beginning of XXI century the Ukrainian society with its civil, democratic and country expansion, with the marketdriven economy, the values of the democratic structure and modern technologies still cannot not solve the problem of material, psychological and social protection of senior citizens and has not created any favourable conditions for their living yet.

Review of recent publications. Population ageing is one of the main issues being within the field of view of all world countries. The very first scholar dealing with psychosocial aspects of senior age is J. Hall, who is also a founder of social gerontology [8]. The USA was the first country which faced the economic problems of elderly people. In the 1930s, it became obvious that socioeconomic difficulties of senior citizens should be considered as not only their own problem, but an urgent social one [9: 254].

The issue of studying emotions has been the subject of research of many philosophers: I. Kant, R. Vallet, I. Vasiliev, L. Vygotsky, S. Rubinstein; as well as pedagogues and psychologists: L. Bozhovich, V. Wundt, B. Dodonov, K. Levin, A. Leontiev, A. Maslow, P. Jacobson. Emotions as a psychological phenomenon are 
considered to be a force determining the inner state and behavior of people.

The works of I. Mechnikov, S. Yakovlev, M. Glezer, F. Komarov covered different aspects of demographic, social, medical and biological aspects of elderly people. I. Mechnikov has laid the foundation of the social approach to the study of gerontological problems by proving the dependence of human organism's ageing on the lifestyle. A famous domestic scholar A. Bohomolets has revealed the dependence of ageing on labour conditions. Besides, the issues of gerontology were considered by such researches as, for example, M. Lukashevich, I. Migovich, M. Pikovyy. A significant contribution to the studying of the issue of elderly people's emotions has been made by Z. Frenzel, N. Sachuk, A. Rubanin, M. Oleksandrova. However, this issue still remains understudied.

The article is aimed at revealing peculiarities of emotional states of senior citizens under modern conditions of complex transformations and reforms of the Ukrainian society.

Major content. Until recently the category of senior citizenship has been determined by domestic psychology as the retirement age (for men it is 60 years, and for women it is 55 years). According to the new pension legislation enacted on the $1^{\text {st }}$ of October, 2011, the only retirement age in Ukraine both for men and women is 60 years [3]. The retirement is accompanied by losing social identity, new feelings and personal emotional experiencing of one's own ageing. The loss of social identity leads to the impossibility of personal self-determination in the social environment [7: 11]. The retired people who spent their entire life working for the benefit of the country now cannot comprehend their place in the modern society. Most of them do not understand the market-driven economy and socio-cultural changes taking place in Ukraine.

Taking into account how little retirement benefit is, which in addition is taxed, and how high the inflation rate is, a retired person becomes a subject of social disrespect and is being treated as unnecessary and unwanted society members.

It is a common knowledge that most of elderly people are prone to experience negative emotions almost all the time. The influence of negative factors, social and economy life conditions make their life more difficult. The emotional states of these people are influenced by the social status and micro environment. The retirement age is characterized by the increase of the level of social and biological adaptation, working capacity and productivity, as well as health deterioration. The inability of a senior citizen to do something useful for somebody causes the complex of inferiority, irritation, which leads to the indifferent attitude towards the environment and the whole world [6].

A person performs certain social roles according to his/her age. The emotions of a person depend on the degree of his/her adaptedness to the conditions of performing these roles. In this way due to the retirement and change of social role and status a person loses social support of the society, feels detachment, loneliness, insecurity, etc. Whatever a person achieves in his/her life and work he/she will face the problem of ageing and retirement.

It is well-known that different things and phenomena have different impact on human sensory organs and cause the conscious reaction of the psyche in the form of feelings and emotions. Emotions are considered to be an integral subjective response of a person to the internal and external stimuli. They are manifested in the form of certain experiences (pleasure, dissatisfaction, sadness, joy, confidence or fear, etc.). They are one of the most important mechanisms of internal regulation of the psyche and behavior, oriented at satisfying material and spiritual needs of a person.

Emotional and volitional processes as psychological phenomena involve emotions, feelings and human will, which influence the psyche in its way. Emotions have a special role of assessing people's activity results and perform organizing, stimulating and steering functions [2: 105].

Feelings are the highest form of manifestation of emotions. They represent the attitude of a person towards social phenomena, other people and oneself. The feelings are stable; they do not depend on the state of an organism or a situation.

Pleasure and displeasure are considered to be the simplest and the most common forms of emotions. Pleasure is reached by a person in case of his/her needs satisfaction, and displeasure is caused by the impossibility of doing this. They are interconnected, which can be explained by the fact that any emotional state is accompanied by many physical changes in an organism. However, modern science still does not have an answer what changes in particular accompany this process [5: 157].

Under extreme conditions when a subject realizes the impossibility of solving a problem, a special type of emotions - affect - is developing. It causes disruptive psychic (fear, rage) and vegetative (cardiac acceleration, sweating, trembling) reactions.

In modern practical psychology all emotional states are distinguished by its influence on the human organism - activation or blocking. The sthenic emotional states are related to the first group and involve cheerfulness, joy, pleasure, enthusiasm, etc. The second group (asthenic states) includes weariness, anxiety, apathy, fear, and psychological tension. Thus, social background and socioeconomic conditions of elderly people's living create asthenic psychic states and threatens their psychic integrity.

Personal changes, types of activity, dynamics of cognitive functions are determined by the character of the major activity, which in the old age can be focused on the saving of one's personality, supporting of his/her social relations, or on the individualization, isolation of an individual against the background of the gradual failure of psycho-physiological functions. Both ways of ageing pro- 
vide different variants of life quality and duration, both are characterized by different emotional experiences and states. According to Polish gerontologist K.VysnevskaRoshkovska, the «opened» organism system turns into «blocked» [1: 9], which is manifested in the general decrease of the interest in the surrounding world, egocentrism, indifference. Elderly people's incapability to do something for another people, unconscious envy and guilt cause inferiority and irritation. Eventually, all of that leads to self-centeredness, touchiness, impatience.

The decrease of the functions of self-determination and self-regulation causes the aggravation of personal characteristics - cautiousness turns into suspiciousness, thriftiness - into greediness. In this aspect the assessment of the state of health and mood are considered to be very important [1: 12]. As a result the conceptual model of reality, according to which the adaptation process takes place, is forming.

In the adaptation strategy oriented at maintaining oneself as an individual, the disparity between the past, present and future acts like a safety element. Emotions are aimed at normalization of old person's psychic states and functions, as well as saving an old person from real life, which cannot be managed by himself/herself anymore. As a rule, the type of the process of getting old is chosen by a person long before he/she reaches the old age. According to it, certain adaptation mechanisms are also selected by a person himself/herself. Some people consider the retirement as tragic isolation from the society, and others regard it as an opportunity to take up a new hobby, which was put away for later. In both cases emotional states play a great role in the process of adaptation.

The studying of emotional sphere of elderly people should contribute to the development of their psychophysiological efficiency. The empirical study aimed at revealing the peculiarities of senior citizens' emotional states was carried out during 2015-2016 with the help of "The questionnaire on studying personality emotional orientation" by B. Dodonov and "Personal questionnaire of accentuation types" by G. Shmishek. The experiment

\section{ЛІТЕРАТУРА}

1. Висьневска-Рошковска К. Новая жизнь после шестидесяти / К. Висьневська-Рошковська. - М., 1989. $-236 \mathrm{c}$.

2. Гаврилова Т. П. О воспитании нравственных чувств / Т. П. Гаврилова. - М. : Просвещение, 1984. $252 \mathrm{c}$.

3. Закон України «Про заходи щодо законодавчого забезпечення реформування пенсійної системи» // Відомості Верховної Ради України. - 2012. - № 1213.

4. Запорожец А. В. Избранные психологические труды : в 2-х т. Т. 1 / А. В. Запорожець. - М. : Педагогика, 1986. -258 с.

"Наука і освіта", №2-3, 2016 involved 60 senior citizens aged from 60 to 78 belonging to two different categories: 1) people who study at "The University of the Third Age" at Alfred Nobel University, Dnipropetrovsk; 2) people who do not take active social position. The sthenic emotional orientation was expected to be associated with the surveyed who studied at the University, unlike those who had isolated lifestyle. According to the research results, $90 \%$ of people from the first group are socially active citizens who have lived out their dream of entering the University and made their knowledge more profound. They are full of positive emotions; take part in different competitions and have a lot of friends. $70 \%$ of the surveyed have made away with the feeling of loneliness, learnt to abstract themselves from everyday problems and illnesses and to make plans for the future. $82 \%$ of them are characterized by altruism and sociability. As distinguished from the first group, $82 \%$ of the senior citizens from the second one have the passive lifestyle and no plans for the future. They noted that one of the most important problems was low retirement benefit, high prices and the lack of relatives and other peoples' care. They have also expressed their negative emotions which have enhanced hostility. $60 \%$ of them have hedonistic emotional orientation.

Conclusions and prospects for further research. It has been determined that emotions have a great impact on human health and life duration, especially on elderly people, who are considered to be unprotected and vulnerable under modern changing conditions and transformations taking place in Ukraine. The carried out empirical research of the peculiarities of senior citizens' emotional states has revealed that socially active elderly people do not lose their interest in life and the surrounding world. They are considered to be happier and healthier than the ones who have passive way of living. Their negative emotions affect their state of health and make their life more difficult.

The adaption problem of elderly people requires further studying. The issue of senior citizens adaptation for changing social conditions is considered to be the relevant prospect of the further researches.

5. Кейд Б., О'Хэнлон В. Х. Краткосрочная психотерапія / Б. Кейд, В. Х. О’Хэнлон. - М. : Институт общегуманитарных исследований, 2001. - 268 с.

6. Коленіченко Т. І. Адаптація людей похилого віку до нових соціальних умов [Електронний ресурс] / T. I. Колесніченко. - Режим доступу: http://www.rusnauka.com/14.NTP_2007/Pedagogica/218 49.doc.htm.

7. Миннигалеева Г. Социально-педагогическая работа с пожилыми людьми : дис. ... канд. пед. наук : 13.00.01 / Г. Миннигалеева. - М., 2004. - 310 с.

8. Новікова О. Ю. Проблеми людини похилого віку: соціально-педагогічний аспект [Електронний ресурс] / О. Ю. Новікова. - Режим доступу: http://bo0k.net/index.php?bid=7939\&chapter=1\&p=achapter 
9. Холл Дж. Старіння, остання половина життя / Дж. Холл. - Вашингтон, 1922. - 322 с.

10. Шевчук Н. Ф. Духовність суспільства крізь призму ставлення до людей похилого віку /

\section{REFERENCES}

1. Vysnevska-Roshkovska, K. (1989). Novaya zhyzn posle shestidesyati [The new life after sixty].Moscow [in Russian].

2. Havrylova, T. P. (1984). O vospytanii nravstvennykh chuvstv [About the instilling of moral sentiments]. Moscow: Prosveshchenie [in Russian].

3. (2012). Zakon Ukrayiny «Pro zakhody shchodo zakonodavchoho zabezpechennia reformuvannia pensiinoi systemy» [Law of Ukraine "On the rightful support of reforming pension legislation"]. Vidomosti Verkhovnoi Rady Ukrayiny - News of the Verkhovna Rada of Ukraine (pp. 12-13) [in Ukrainian].

4. Zaporozhets, A. V. (1986). Izbrannye psikholohycheskie trudy: v 2-kh t. [The selected psychological works: in 2 volumes]. Moscow: Pedagogika [in Russian].

5. Keyd, B., O'Khenlon, V. Kh. (2001). Kratkosrochnaya psykhoterapiya. [The short-term psychotherapy]. Moscow: Institut obshchegumanitarnykh issledovaniy [in Russian].

6. Kolenichenko, T. I. (2007). Adaptatsiya lyudey pokhyloho viku do novykh sotsialnykh umov [The adap-
Н. Ф. Шевчук // Духовність особистості: методологія, теорія і практика. - № 5 (40). - 2010. - С. 253-263.

tion of elderly people to new social conditions]. Retrieved from: http: // www.rusnauka.com/14.NTP_2007/Pedagogica/21849.doc .htm [in Ukrainian].

7. Mynnyhaleeva, H. (2004). Sotsialnopedagogicheskaya rabota s pozhylymi lyudmi [The social and pedagogical work with old people]. Candidate's thesis. Moscow [in Russian].

8. Novikova, O. Yu. Problemy liudyny pokhyloho viku: sotsialno-pedahohichnyi aspect [The problem of an old man: the social-pedagogical aspect]. Retrieved from: http://bo0k.net/index.php?bid=7939\&chapter=1\&p=achapter.

9. Kholl, Dzh. (1922). Starinnia, ostannia polovyna zhyttia [The aging, the last half of life]. Washington [in Ukrainian].

10. Shevchuk, N. F. (2010). Dukhovnist suspilstva kriz pryzmu stavlennia do lyudey pokhyloho viku [The spirituality through the prism of relation to the elderly people]. Dukhovnist osobystosti: metodolohiya, teoriya i praktyka The personality spirituality: the methodology, the theory and the practice, 5(40), 253-263 [in Ukrainian].

Тамара Миколаӥвна Плаксій, кандидат історичних наук, доиент кафедри психологіï, педагогіки та філософії,

Микола Анатолійович Деркач, студент IV курсу напряму «Психологія», Кременчуиький національний університет імені Михайла Остроградського, вул. Першотравнева, б. 20, м. Кременчук, Украӥна

\section{ОСОБЛИВОСТІ ЕМОЦІЙНИХ СТАНІВ ЛЮДЕЙ ПОХИЛОГО ВІКУ В УМОВАХ ТРАНСФОРМАЦІЇ СУЧАСНОГО УКРАЇНСЬКОГО СУСПІЛЬСТВА}

Стаття присвячена дослідженню особливостей емоційних станів людей особливої категорії - похилого віку - в сучасних умовах суперечливих процесів модернізації усіх сфер українського суспільства. Проблема емоційної сфери особистості людини похилого віку сьогодні проникнута особливим значенням та драматизмом: населення України стрімко старіє, збільшується кількість людей похилого віку, при цьому умови їх життя значно погіршуються. Держава і суспільство не можуть створити гідні умови для їх життя. Мета статті полягає в аналізі понять «пенсійний вік», «похилий вік», «емоції», «емоційні стани», «емоційні переживання», «почуття» та у виявленні особливостей емоційних станів, обумовлених зовнішніми та внутрішніми подразниками. Було встановлено, що переважна більшість людей пенсійного віку не сприймають ринкових соціально-економічних умов життя «дикого капіталізму», політичного хаосу в державі, соціально-культурних змін, що відбулися за роки розбудови незалежної України, особливо за останні два роки. Враховуючи, яким мізерним є пенсійне забезпечення, що ще й обкладається принизливим податком, і якою великою є інфляція в країні, то тут пенсіонер постає об'єктом зневаги, приниження його людської гідності з боку держави. Як правило, переважаючим у людей похилого віку в Україні є адаптаційний процес за «замкнутим контуром» - від найбільш негативного до найбільш позитивного, за якого світ постає як незрозумілий, непередбачуваний, інколи загрожує загибеллю. Людина не «володіє» таким світом, є соціально непричетною до нього, перспективи власного життя не залежать від неї, а стратегія поведінки описується буденним поняття «доживати свій вік». На основі емпіричного дослідження за допомогою опитувальника з вивчення емоційної спрямованості особистості Б. Додонова та особистісного опитувальника для діагностування типу акцентуацій Г. Шмішека доведено, що люди, які відвідують Університет третього віку, мають активну життєву позицію, у них переважає стенічна емоційна спрямованість, а також спрямованість на альтруїз, комунікативність, праксизм, гностизм, естетизм. На відміну від них 
особи другої категорії - люди із пасивною життєвою позицією, спосіб життя яких замкнений, відчужений. Вони відзначили, що найбільш важливою для них проблемою є недостатність пенсійних коштів для життя, дорожнеча, неувага з боку родичів та суспільства. Ці обставини їх пригнічують. При цьому вони висловили негативні почуття, які посилили їх і без того вороже ставлення до суспільства, відсутність планів на найближче майбутнє. У них переважає гедоністична та акизитивна емоційна спрямованість. Проблема адаптації людей похилого віку до соціальних умов буття потребує подальших розробок.

Ключові слова: емоції, емоційні стани, емоційні переживання, емоційна сфера, похилий вік, пенсійний вік.

\section{Тамара Николаевна Плаксий кандитат исторических наук, дочеет кафедры психологии, педагогики и философии, \\ Николай Анатольевич Деркач, \\ студент IV курса направления подготовки «Психология», Кременчугский национальньй университет имени Михаила Остроградского, ул. Первомайская, 20, г. Кременчуг, Украина \\ ОСОБЕННОСТИ ЭМОЦИОНАЛЬНЫХ СОСТОЯНИЙ ЛЮДЕЙ ПОЖИЛОГО ВОЗРАСТА В УСЛОВИЯХ ТРАНСФОРМАЦИИ СОВРЕМЕНОГО УКРАИНСКОГО ОБЩЕСТВА}

Статья посвящена исследованию особенностей эмоциональных состояний особой социальной категории людей пожилого возраста - в современных условиях противоречивых процессов модернизации всех сфер украинского общества. Проблема эмоциональной сферы личности человека пожилого возраста пронизана особым значением и драматизмом: население Украины стремительно стареет, увеличивается количество пожилых людей, при этом условия их жизни значительно ухудшаются. Государство и общество не могут создать достойные условия для их жизни. Цель статьи состоит в анализе понятий «пенсионный возраст», «пожилой возраст», «эмоции», «эмоциональные состояния», «эмоциональные переживания», «чувства» и в выявлении особенностей эмоциональных состояний, которые обусловлены внешними и внутренними раздражителями. Установлено, что подавляющее большинство людей пенсионного возраста не воспринимают рыночных социальноэкономических условий жизни «дикого капитализма», политического хаоса в государстве, социальнокультурных изменений, которые произошли за время независимости Украины, особенно за два последних года. Учитывая то, каким мизерным является пенсионное обеспечение, которое к тому же облагается унизительным налогом, и какой большой уровень инфляции в стране, то пенсионер чувствует себя объектом презрения, унижения его человеческого достоинства со стороны государства. У людей пожилого возраста в Украине преобладает адаптационный процесс по «замкнутому контуру» - от наиболее отрицательного до наиболее положительного, при котором мир представляется как непонятный, непредсказуемый, иногда угрожающий гибелью, при котором человек не «владеет» таким миром, социально непричастный к нему, перспективы собственной жизни человека от него самого не зависят. Стратегию поведения такого человека можно описать обыденными словами «доживать свой век». На основании эмпирического исследования, осуществленного при помощи опросника по изучению эмоциональной направленности личности Б. Додонова, а также личностного опросника для диагностирования типа акцентуаций Г. Шмишека, установлено, что люди, которые посещают Университет третьего возраста, обладают активной жизненной позицией. У них преобладает стеническая эмоциональная направленность, а также направленность на альтруизм, коммуникативность, праксизм, гностизм, эстэтизм. В отличие от них люди с пассивной жизненной позицией, образ жизни которых замкнутый, отчужденный, отметили, что наиболее важной для них проблемой есть недостаточность пенсионных средств, подорожание, невнимательность со стороны родственников и общества. Эти обстоятельства их угнетают. При этом они выразили отрицательные чувства, которые усилили враждебное отношение к обществу, отсутствие планов на ближайшее будущее. У них преобладает гедонистическая и акизитивная эмоциональная направленность. Проблема адаптации людей пожилого возраста к социальным условиям бытия ожидает дальнейших разработок.

Ключевые слова: эмоции, эмоциональное состояние, эмоциональные переживания, эмоциональная сфера, пожилой возраст, пенсионный возраст.

Подано до редакиії 01.03.2016 